\title{
LYMPHOCYTE-T TYPE TH1 AND TH2 ACTIVITY DIFFERENCE OF LUNG TISSUE ON Heligmosomoides polygyrus NEMATODE AND Mycobacterium tuberculosis SEQUENTIAL CO-INFECTION
}

\author{
Laksmi Wulandari ${ }^{1}$, Muhammad Amin ${ }^{1}$, Soedarto ${ }^{2}$, Gatot Soegiarto ${ }^{3}$ \\ ${ }^{1}$ Pulmonology and Respiratory Medicine Department, ${ }^{2}$ Parasitology Department, Dr. Soetomo Hospital, ${ }^{3}$ Internal \\ Medicine Department, Faculty of Medicine, Airlangga University, Surabaya, Indonesia
}

\begin{abstract}
ABSTRAK
Tuberkulosis (TB) merupakan penyakit infeksi kronik, disebabkan oleh Mycobacterium tuberculosis yang sering dikaitkan dengan rendahnya efektivitas vaksin BCG dan tingginya infeksi cacing. Tujuan penelitian ini adalah untuk mengetahui perbedaan aktivitas

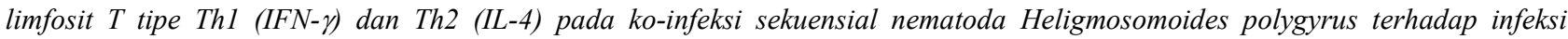
Mycobacterium tuberculosis. Penelitian ini menggunakan 49 ekor mencit yang terbagi menjadi 7 kelompok perlakuan dengan infeksi oleh Mycobacterium tuberculose secara inhalasi dan Heligmosomoides polygyrus secara per oral dalam waktu 8 dan 16 minggu. Kadar IFN- $\gamma$ dalam serum darah tepi $(89,929 \pm 3,533 \mathrm{pg} / \mathrm{mL})$ memiliki gambaran yang menyerupai pola prosentase limfosit $T$ CD4+ Th1 di jaringan paru $(3,246 \pm 0,519 \%)$ dan darah tepi $(4,950 \pm 0,237 \%)$, sedangkan kadar IL-4 dalam serum darah tepi $(20,782 \pm 4,043 \%)$ memiliki gambaran yang menyerupai pola prosentase limfosit T CD4+ Th2 di jaringan usus (1,048 $\pm 0,359 \%)$ dan darah tepi $(1,196 \pm 0,557 \%)$. Simpulan, Terdapat perbedaan aktivitas limfosit T tipe Th1 dan Th2 namun tidak mempengaruhi respons imun terhadap infeksi Mycobacterium tuberculosis. (FMI 2017;53:124-130)
\end{abstract}

Kata kunci: Mycobacterium tuberculosis, Heligmosomoides polygyrus, IFN- $\gamma, I L-4$

\begin{abstract}
Tuberculosis (TB) is a chronic infectious disease caused by Mycobacterium tuberculosis that are often associated with uneffectiveness of the BCG vaccine and the high worm infection. The objective of this study was to determine the differences in the activity of Limfosit T type Th1 (IFN- $\gamma$ ) and Th2 (IL-4) in lung tissue on Heligmosomoides polygyrus nematode and Mycobacterium tuberculosis sequential co-infection. This research using 49 mice were divide into 7 groups treated with infection by Mycobacterium tuberculose inhaled and Heligmosomoides polygyrus orally within 8 and 16 weeks. The levels of IFN- $\gamma$ in peripheral blood serum $(89.929 \pm 3.533 \mathrm{pg} / \mathrm{mL})$ resembles the pattern of the percentage of lymphocytes T CD4+ Th1 in lung tissue (3.246 $\pm 0.519 \%)$ and peripheral blood $(4.950 \pm 0.237 \%)$, while the levels IL-4 in the peripheral blood serum $(20.782 \pm 4.043 \%)$ resembles the pattern of the percentage of lymphocytes T CD4+ Th2 in intestinal tissue $(1.048 \pm 0.359 \%)$ and peripheral blood $(1.196 \pm 0.557 \%)$. In conclusion, there is difference in the activity of lymphocytes T type Th1 and Th2 but it does not affect the immune response to Mycobacterium tuberculosis infection. (FMI 2017;53:124-130)
\end{abstract}

Keywords: Mycobacterium tuberculosis, Heligmosomoides polygyrus, IFN- $\gamma, I L-4$

Correspondence: Laksmi Wulandari, Pulmonology and Respiratory Medicine Department, Faculty of Medicine, Airlangga University, Dr Soetomo Hospital, Jalan Prof dr Moestopo 6-8, Surabaya 60286, Indonesia.

\section{INTRODUCTION}

Tuberculosis (TB) is a chronic infection caused by $M y$ cobacterium tuberculosis with a mortality rate of around 1.4 million per year, especially in developing and lowincome countries (WHO 2012). The high incidence rate of TB in most areas of the country is closely related to the effectiveness of low BCG vaccination and the high prevalence of worm infections (Fine et al 1995, Lipner et al 2006, Elias et al 2007).

Mycobacterium tuberculosis, a facultative intracellular paracid bacillus bacterium (Todar 2009) can be eliminated by cellular immunity played by macrophages; CD4+ T-lymphocytes that secrete IFN- $\gamma$; CD8 + T lymphocytes that kill macrophages infected with TB germs; as well as $\mathrm{T}$ lymphocytes $\gamma \delta$ (Schluger et al 2005) in which the immune response requires a strong Th1 type of cytokine (van Crewel et al 2002). In contrast, worm infections stimulate the activation of eosinophil cells, mast cells, basophile cells, and IgE formation, which is a Th2-type immune response (Anthony et al 2007).

The dominant Th2-type immune response suppresses the Th1 immune response through suppression by IL-4 which proves that worm infections can suppress the immune response to the TB germs (Resende et al 2006, Potian et al 2007, Bhatt et al 2007). In contrast, Erb et al (2002) and Frantz et al (2007) reported that worm or 
parasite infections did not alter immunity to mycobacteria in mice-treated animals, in which dendritic cells mutually stimulated using bacterial antigens and worm antigens were able to undergo maturation and induce both Th1-type immune responses and Th2-type immune responses. The existence of differences in the results of these studies to date have not been able to be drawn conclusions that are certain and satisfactory.

Research on the co-infection of Nematoda Heligmosomoides polygyrus worm in mice previously infected with Mycobacterium tuberculosis as a sequential standard model is very necessary to be done to determine the difference of $\mathrm{T} 1$ and $\mathrm{Th} 2$ type $\mathrm{T}$ lympho-cyte cell activity so that TB can be effectively controlled effectively.

\section{MATERIALS AND METHODS}

The research was conducted for 6 (six) months with the location of the research is at Animal Cage Try the Parasitology Division of Clinic Faculty of Medicine Universitas Brawijaya and in Bacteriology Laboratory of Tuberculosis Infection Study Group of Tropical Diseases Institution Airlangga University Surabaya.

The sample size or replication is the number of treatments in an experiment (r). Replication affects the number of replicates (r) of a study. Using the large formula of Steel and Torrie samples (1980) and Higgins correction factor formulas to anticipate a drop out with an estimated $55 \%$. The total sample size was 49 male (Mus musculus) mice of wild type type which was 8-12 mingggu with body weight 30-35 gram.

Mice were divided into 7 groups consisting of: Mycobacterium tuberculosis-infected group for 8 weeks (M.tb8), tuberculosis infected group (Mycobacterium tuberculosis) for 16 weeks (M.tb16), a group infected with a worm (Heligmosomoides polygyrus ) for 8 weeks (H.pg8), a worm infected group (Heligmosomoides polygyrus) for 16 weeks (H.pg16), a group of mice treated with helminths (Heligmosomoides polygyrus) followed by TB infection (Mycobacterium tuberculosis) (H.pg + M.tb), a group of mice treated with TB coinfection (Mycobacterium tuberculosis) followed by a helminth infections (Heligmosomoides polygyrus) (M.tb + H.pg), as well as infectious groups as controls. At the end of the 16th week (ie 8 weeks after the last infection treatment sequence), the study subjects of all treatment groups will be evaluated by taking peripheral blood specimens for the measurement of some IL-4 and IFNcytokines with ELISA method.

\section{Mycobacterium tuberculosis infection method}

Mice Balb/c presented 10mL PBS-Tween 80 solution containing 106 Mycobacterium tuberculosis inhalation using a modified nose only inhalation system or Middlebrook Inhalation Exposure System (GLAC-Col) for 30 minutes in inhalation chamber placed in a large box filtered HEPA.

\section{Method of Heligmosomoides polygyrus Infection}

Balb/c mice were inoculated with oral Heligmosomoides polygyrus larvae with a blunt-specially-sided blistering syringe containing $100 \mu \mathrm{L}$ PBS solution containing $2000 \mathrm{~L} 3 / \mathrm{mL}$. Gavage needle is inserted into the esophagus and the contents are sprayed slowly to avoid regurgitation (Camberis et al., 2003).

\section{Processing and analysis of data}

The data of the research variables were analyzed for distribution by group with Shapiro-Wilk test. Data that is not normally distributed will be tested by KruskalWallis, while the normal distributed data is tested by homogeneity of variance. The homogeneous variance will be analyzed by ANOVA test, while the non homogeneous variance will be analyzed by Brown-Forsythe test.

\section{RESULTS}

\section{Effect of treatment on Th-1 lymphocyte activity}

Th1 $\mathrm{T}$ lymphocyte activity is characterized by the production of Interferon- $\gamma$ (IFN- $\gamma$ ) cytokines in peripheral blood measured by the ELISA method and the percentage of CD4+ T lymphocytes expressing the IFN$\gamma$ intracellular as measured by flowsitometry in lung tissue, intestinal tissue, and peripheral blood. In the coinfection group of $M$. tuberculosis and $H$. Polygyrus there is a tendency that high levels of IFN- $\gamma$ determined by the last sequence of infection, in which the group treated with the last co-infection was $M$. tuberculosis infection IFN- $\gamma$ level $(89,929 \pm 3,533 \mathrm{pg} / \mathrm{mL})$ was significantly higher than the group treated with the last co-infection of $H$. Polygyrus infection $(46,168,7,821$ $\mathrm{pg} / \mathrm{mL}$ ) seen in Table 1 and Figure 1. 
Table 1. IFN- $\gamma$ level in peripheral blood serum

\begin{tabular}{|c|c|c|c|c|}
\hline \multirow{2}{*}{ Treatment groups } & \multicolumn{3}{|c|}{ Peripheral blood serum ELISA $(\mathrm{pg} / \mathrm{mL})$} & \multirow[b]{2}{*}{$\mathrm{p}$} \\
\hline & Mean \pm SD & Min & $\operatorname{Max}$ & \\
\hline H.pg 8 & $8.564 \pm 1.414^{\mathrm{a}}$ & 7.278 & 10.949 & 0.000 \\
\hline H.pg 16 & $29.463 \pm 6.279^{b}$ & 22.203 & 38.696 & \\
\hline H.pg + M.tb & $89.929 \pm 3.533^{\mathrm{e}}$ & 85.127 & 93.354 & \\
\hline M.tb + H.pg & $46.168 \pm 7.821^{c}$ & 38.852 & 58.127 & \\
\hline M.tb 16 & $62.975 \pm 7.824^{d}$ & 51.203 & 72.089 & \\
\hline M.tb 8 & $106.481 \pm 5.446^{f}$ & 99.620 & 114.747 & \\
\hline Control & $7.207 \pm 2.034^{\mathrm{a}}$ & 4.747 & 10.342 & \\
\hline
\end{tabular}

Notes: H.pg: H. Polygyrus infection; M.tb: M. tuberculosis infection; 8 and 16: infection for 8 and 16 weeks; The letters a, b, c, d, e, f: indicate that groups with the same letter marks have insignificant differences, whereas groups with different letter marks have significant differences.
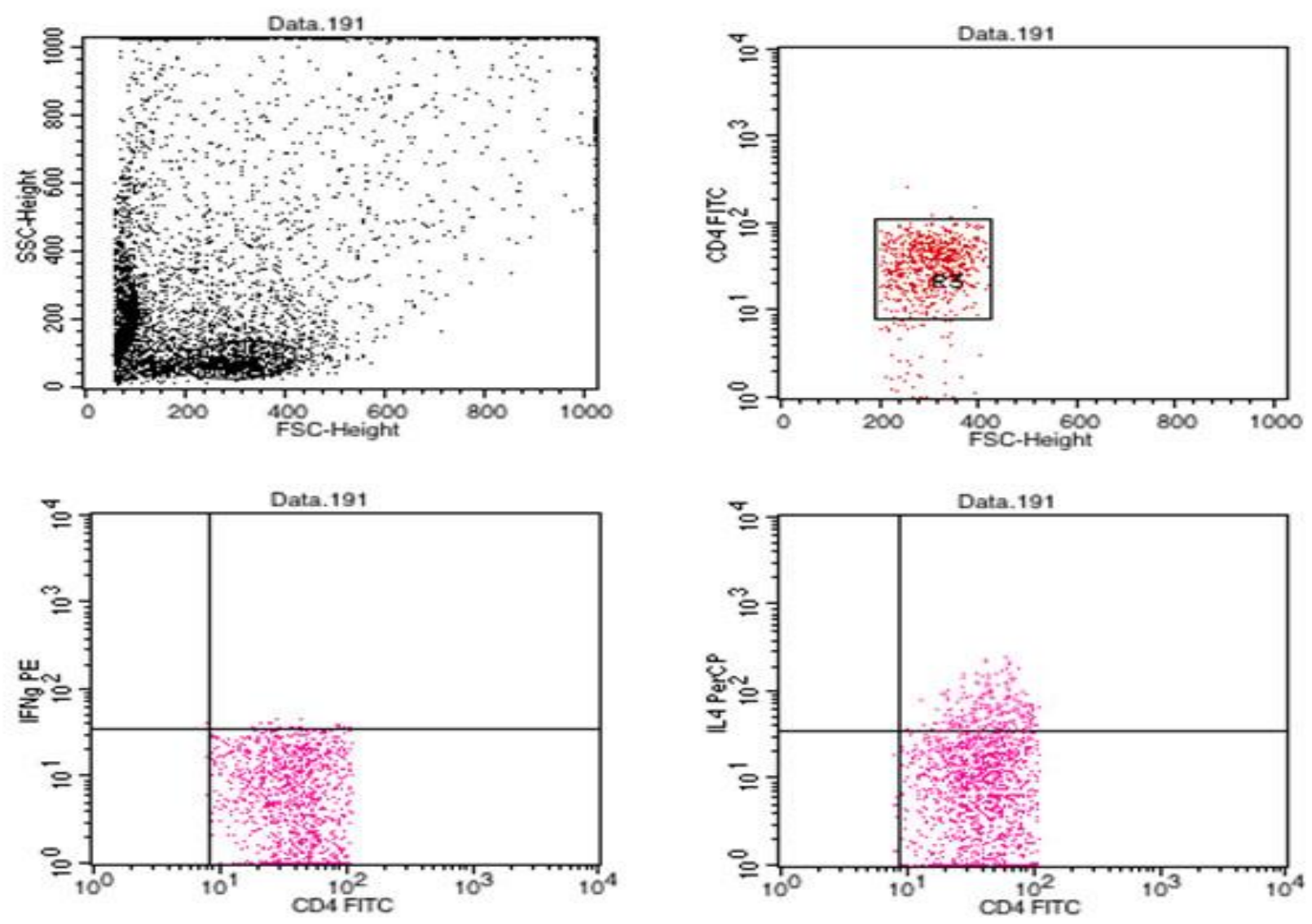

\begin{tabular}{|c|c|c|c|}
\hline Quad & Events & $\%$ Gated & \% Total \\
\hline u & 1 & 0.03 & 0.01 \\
\hline UR & 12 & 3.08 & 0.08 \\
\hline LL & 20 & 0.56 & 0.13 \\
\hline UR & 3444 & 96.34 & 22.08 \\
\hline
\end{tabular}

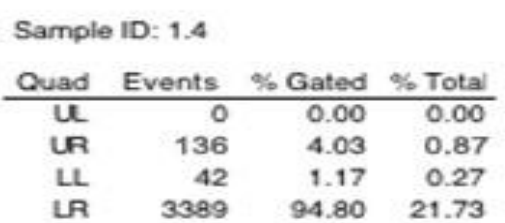

Figure 2. Flowcytometry results of CD4+ T lymphocytes in lung tissue 


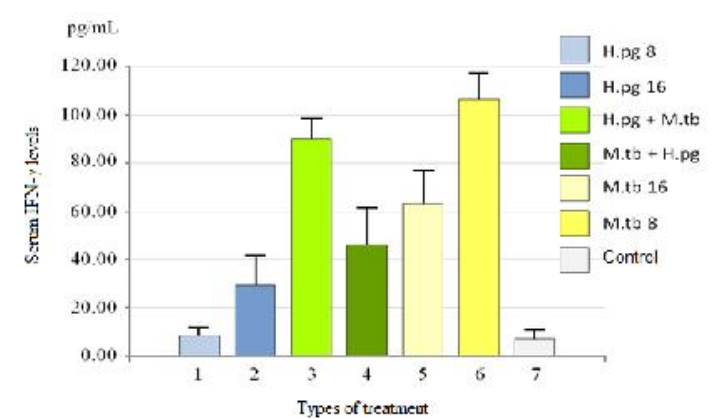

Figure 1. IFN- $\gamma$ level in blood serum $(\mathrm{pg} / \mathrm{mL})$

Percentage of CD4+ T lymphocytes expressing the IFN$\gamma$ molecule intracellular in lung tissue, intestinal tissue, and peripheral blood were measured by flowsytometry technique using antibodies against CD4 and INF- $\gamma$ simultaneously with the FACSCalibur tool and the CellQuest software obtained the number of cell percentages in question and the dot plot visualization in the upper right quadrant of each graph as shown in Fig. 2.

CD4+ T lymphocytes were identified with anti-CD4 antibodies that were conjugated with fluoro- chrome fluorescein isothiocyanate (FITC) (top right). Furthermore, permeabilization and identification of CD4+ T lymphocytes expressing IFN- $\gamma$ intracellular with antiIFN- $\gamma$ antibodies conjugated with phycoerythrin (PE) (bottom left) or expressing IL-4 with anti-IL-4 antibodies conjugated with peridinin chlorophyll protein (perCP) (bottom right). In the table at the bottom of the dot plot can be read the percentage of events in the upper right quadrant (UR). This figure represents the measurement in the treatment group no. 1 member no. 4.

This technique is a technique of calculating intracellular cytokines directly without in vitro stimulation. CD4+ T lymphocytes expressing the IFN- $\gamma$ molecule intracellular percentage is very low (less than 6\%), but the percentage pattern in each type of treatment group can still be seen in Figures 3, 4, and 5.

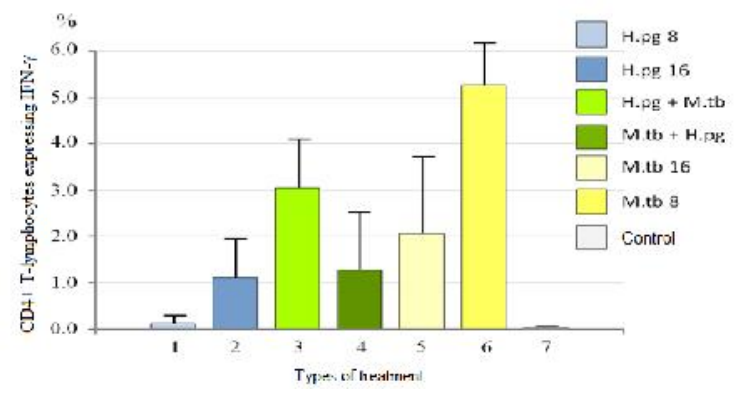

Figure 3. CD4+ T-lymphocytes expressing IFN $-\gamma$ in lung tissue
The highest percentage of CD4+ T -1 lymphocytes in lung tissue (Fig. 5.3) was highest in M. tuberculosis infection for 8 weeks $(4.508 \mu .947)$ and then decreased in $M$. tuberculosis infection for 16 weeks $(2.058 \times$ 0.845). H. Polygyrus infection for 8 weeks had a low percentage of CD4+ T1 lymphocytes (equivalent to control) and then increased in infection for 16 weeks. The group treated with the last co-infection in the form of $M$. tuberculosis infection had a significantly higher percentage of CD4+ T1 T lymphocytes than the opposite co-infection.

The calculated percentage of CD4+ T1 lymphocyte T lymphocytes in intestinal tissue showed no significant intergroup differences (Brown-Forsythe test, $\mathrm{p}=0.109$; $\mathrm{p}>0.05)$ as shown in Figure 4.

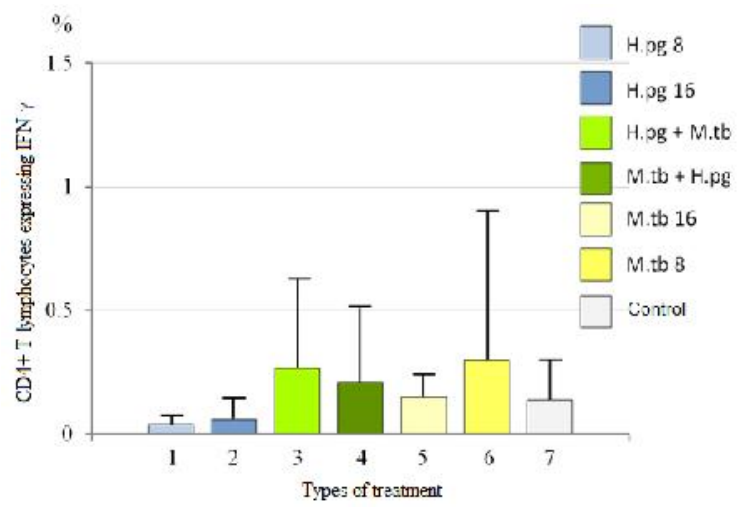

Figure 4. CD4+ T-lymphocytes expressing IFN- $\gamma$ on the intestinal tract

The calculated percentage of CD4+ Th1 lymphocyte T lymphocytes in peripheral blood showed that the group treated with the last co-infection of $M$. tuberculosis infection had a significantly higher percentage of CD4+ $\mathrm{T} 1 \mathrm{~T}$ lymphocytes than the opposite co-infection, as shown in Figure 5.

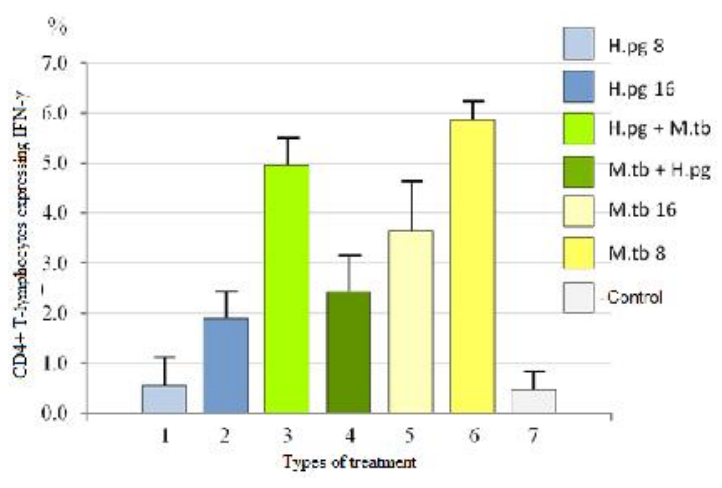

Figure 5. CD4+ T-lymphocytes Expressing IFN- $\gamma$ in peripheral blood 
Lymphocyte CD4+ T1 lymphocyte graph pattern shows a tendency that IFN- $\gamma$ in peripheral blood serum has a picture that more closely resembles the CD4+ Th1 lymphocyte $\mathrm{T}$ lymphocyte pattern in lung tissue and peripheral blood, in contrast to the CD4+ T1 lymphocyte $\mathrm{T}$ lymphocyte pattern in the intestinal tract (Fig. 1 to Fig. 5).

\section{The Effect of treatment on T-type Th2 lymphocyte activity}

Th2-type T lymphocyte activity is characterized by the production of the interleukin-4 (IL-4) cytokine in peripheral blood measured by the ELISA method and the percentage of $\mathrm{CD} 4+\mathrm{T}$ lymphocytes expressing intracellular IL-4 molecules as measured by flowcitometry in lung tissue, intestinal tissue and peripheral blood.

In the co-infection group M. tuberculosis and H. Polygyrus it appears that significantly higher levels of IL-4 in peripheral blood $(\mathrm{p}=0.009 ; \mathrm{p}<0.05)$ were higher when the latter co-infection was $H$. Polygyrus infection $(66,625 \pm 13,937 \mathrm{pg} / \mathrm{mL})$ than when the last coinfection treatment of $M$. tuberculosis infection (20.782 $\pm 4,043 \mathrm{pg} / \mathrm{mL}$ ) can be seen in Table 2 and Figure 6 .

Table 2. Peripheral blood ELISA in treatment groups

\begin{tabular}{|c|c|c|c|c|}
\hline \multirow{2}{*}{$\begin{array}{c}\text { Treatment } \\
\text { groups }\end{array}$} & \multicolumn{3}{|c|}{ Peripheral blood ELISA (pg/mL) } & \multirow[b]{2}{*}{$\mathrm{p}$} \\
\hline & Mean \pm SD & Min & $\operatorname{Max}$ & \\
\hline H.pg 8 & $93.887 \pm 7.279^{\mathrm{a}}$ & 83.647 & 102.018 & 0.000 \\
\hline H.pg 16 & $78.964 \pm 12.376^{\mathrm{a}}$ & 66.912 & 96.930 & \\
\hline H.pg + M.tb & $20.782 \pm 4.043^{b}$ & 17.070 & 26.754 & \\
\hline M.tb + H.pg & $66.625 \pm 13.937^{\mathrm{a}}$ & 49.982 & 83.772 & \\
\hline M.tb 16 & $16.961 \pm 5.209^{b}$ & 11.035 & 22.895 & \\
\hline M.tb 8 & $14.007 \pm 4.418^{\text {b.c }}$ & 9.632 & 20.175 & \\
\hline Control & $5.014 \pm 1.357^{\mathrm{c}}$ & 3.140 & 6.930 & \\
\hline
\end{tabular}

Notes: H.pg: H. Polygyrus infection; M.tb: M. tuberculosis infection; 8 and 16: infection for 8 and 16 weeks; The letters a, b, c,: indicate that groups with the same letter marks have insignificant differences, whereas groups with different letter marks have significant differences

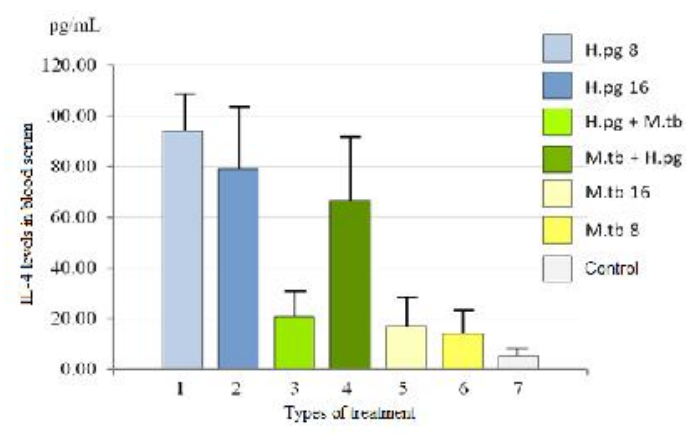

Figure 6. IL-4 levels in blood serum $(\mathrm{pg} / \mathrm{mL})$
The results of the CD4+ Th2 lymphocyte T lymphocyte count in lung tissue showed no significant differences between the treatment groups of infections, but all the treatment group data were significantly different than the control group (Games-Howell Test, $\mathrm{p}<0.05$ ) as shown in Fig. 7.

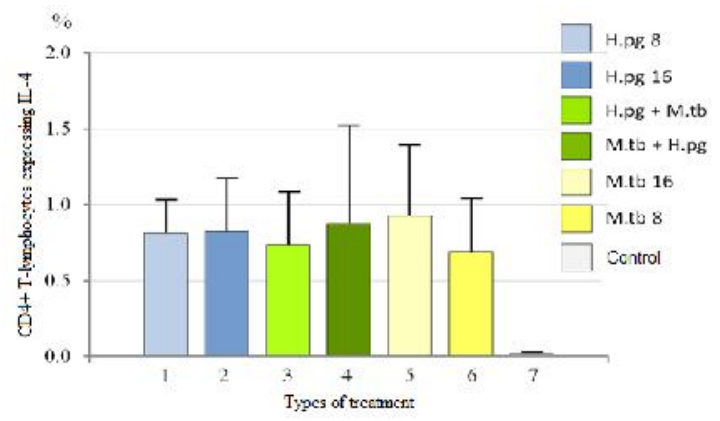

Figure 7. CD4+ T-lymphocytes expressing IL-4 in lung tissue

The calculated percentage of CD4+ Th2 lymphocyte T lymphocytes in the intestinal tract showed M. tuberculosis infection for 8 weeks and for 16 weeks had low CD4+ T2 lymphocyte percentage (equivalent to control group). The group that received the last co-infection treatment in the form of $H$. Polygyrus infection had a significantly higher percentage of CD4+ Th2 lymphocyte $\mathrm{T}$ than those treated with the last co-infection with M. tuberculosis infection $(2,712,0,502$ vs. $1,048 \pm$ $0,359 ; \mathrm{p}=0.005, \mathrm{p}<0.05)$ as shown in Figure 8 .

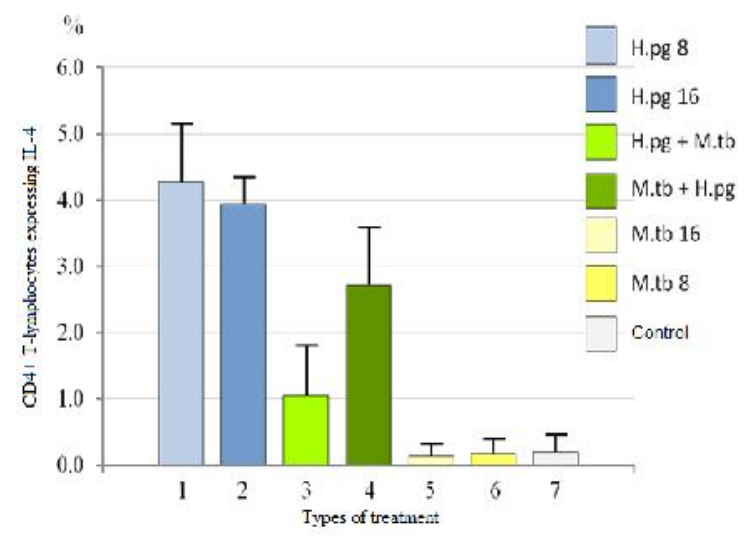

Figure 8. CD4+ T-lymphocytes expressing IL-4 in intestinal tissue

The CD4+ Th2 lymphocyte T lymphocyte count in peripheral blood showed $M$. tuberculosis infection for 8 weeks had a low percentage of lymphocytes of T-CD4+ Th2 $(0.844 \pm 0.178)$, equivalent to 16 weeks of infection of M. tuberculosis $(0.964 \pm 0.273)$ and control group $(0.334 \pm 0.155)$. The group that received the last co- 
infection treatment in the form of $M$. tuberculosis infection had a significantly lower percentage of CD4+ Th2 lymphocytes than the group treated with the last coinfection of $H$. Polygyrus infection as shown in Figure 9.

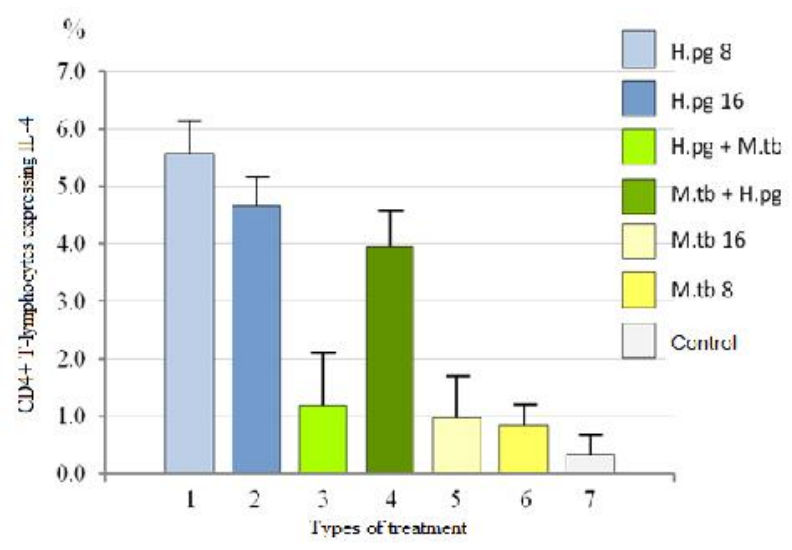

Figure 9. CD4+ T-lymphocytes expressing IL-4 in peripheral blood

\section{DISCUSSION}

Lymphocyte CD4+ Th2 lymphocyte pattern pattern shows a tendency that the pattern of IL4 levels in peripheral blood serum has a picture that more closely resembles the CD4+ Th2 lymphocyte $\mathrm{T}$ lymphocyte pattern in intestinal and peripheral blood tissue, in contrast to the CD4+ Th2 lymphocyte T lymphocyte pattern in lung tissue (Figure 9).

The role of $\mathrm{T}$ lymphocytes in the immune response to M. tuberculosis infection is undoubtedly, where a specific new immune response forms 2-3 weeks after the onset of infection. Tissue lymphocytes accumulate at the site of infection, proliferate and secrete cytokines, especially IFN- $\gamma$. Protective immune responses to $M$. tuberculosis are more necessary for the role of Th1 type cytokines (van Crevel et al., 2002). Th1-type cytokines, among others, IFN- $\gamma$, are needed not only to activate macrophages (Shi et al., 2003) but also to assist the activity of CD8 + T lymphocytes (Salgame 2005; Vesosky et al., 2006) .

In this study, there was an increase in the percentage of Th1 lymphocytes in lung tissue and in peripheral blood that correlated strongly with IFN- $\gamma$ cytokine levels in peripheral blood serum. The increase occurred in the infection of $M$. tuberculosis for 8 weeks which subsequently 'subside' at the time of infection lasting up to 16 weeks, which is consistent with the results of several other researchers who found that elevated levels of IFN- $\gamma$ primarily in the early stages of infection, especially after the second week after infection (Shi et al., 2003; Vesosky et al., 2006). In contrast the role of Th2 lymphocytes is very limited, as evidenced by the low percentage of Th2 lymphocytes in lung tissue and peripheral blood and levels of IL-4 cytokine in peripheral blood serum in $M$. tuberculosis infection for 8 weeks. Levels of IL-4 in new blood increased in the treatment of $H$. Polygyrus infection. Increased levels of IL-4 in peripheral blood serum correlated with the percentage of Th2 lymphocytes in the intestinal and peripheral blood tissue but did not affect the percentage of Th2 lymphocytes in lung tissue.

In the co-infected group, the levels of IL-4 in peripheral blood serum only increased when the last treatment of infection was $H$. Polygyrus infection. Nematode worm infection in the intestine does have a systemic effect on peripheral blood circulation but does not affect the percentage of Th1 or Th2 lymphocytes in lung tissue, so it can be concluded that chronic worm infection has no effect on M. tuberculosis infection.

\section{CONCLUSION}

Sequential co-infection of Heligmosomoides polygyrus and Mycobacterium tuberculosis leads to differences in $\mathrm{T} 1$ and Th2 type T lymphocyte activity in intracellular expressing IFN- $\gamma$, IFN- $\gamma$ level in peripheral blood serum, intracellular IL-4 molecule and IL-4 levels in peripheral blood serum, but the changes do not affect mmune response to Mycobacterium tuberculosis infection.

\section{REFERENCES}

Anthony RM, Rutitzky LI, Urban JF, Stadecker MJ, Gause WC (2007). Protective immune mechanisms in helminth infection. Nature Rev Immunol 7, 975-987

Bhatt K, Liu Z, Gause WC, Salgame P, 2007. Nippostrongylus brasiliensis infection modulates Mycobacterium tuberculosis induced Th1 respone. J. Immunol 178, S45

Camberis M, Le Gros G, Urban J Jr (2003). Animal model of Nippostrongylus brasiliensis and Heligmosomoides polygyrus. Curr Protocols Immunol 55, 19.12.1-19.12.27

Elias D, Britton S, Kassu A, Akuffo H (2007). Chronic helminth infections may negatively influence immunity against tuberculosis and other diseases of public health importance. Expert Rev Anti Infect Ther 5, 475-484

Erb KJ, Trujillo C, Fugate M, Moll H (2002). Infection with the helminth Nippostrongylus brasiliensis does 
not interfere with efficient elimination of Mycobacterium bovis $\mathrm{BCG}$ from the lungs of mice. Clin Diagn Lab Immunol 9, 727-730

Fine PE (1995). Variation in protection by BCG: implications of and for heterologous immunity. Lancet 346, 1339-1345

Frantz FG, Rosada RS, Turato WM, et al (2007). The immune respone to Toxo-cariasis does not modify susceptibility to Mycobacterium tuberculosis infection in BALB/c mice. Am J Trop Med Hyg 77, 691-698

Lipner EM, Gopi PG, Subramani R, et al (2006). Coincident filarial, intestinal helminth, and mycobacterial infection: Helminths fail to influence tuberculin reactivity, but BCG influences hookworm prevalence. Am J Trop Med Hyg 74, 841-847

Potian JA, Bhatt K, Liu Z, et al (2007). Helminthic infection enhances susceptibility to tuberculosis in a murine coinfection model. J. Immunol 178, S42

Resende T, Hirsch CS, Toossi Z, et al (2006). Intestinal helminth co-infection has a negative impact on both anti-Mycobacterium tuberculosis immunity and clinical respone to tuber-culosis therapy. Clin Exp Immunol 147, 45-52

Salgame P (2005). Host innate and Th1 responses and the bacterial factors that control Mycobacterium tuberculosis infection. Curr Opin Immunol 17, 374380
Schluger NW (2005). The pathogenesis of tuberculosis: the first one hundred (and twenty three) years. Am J Respir Cell Mol Biol 32, 251-256

Shi L, Jung YJ, Tyagi S, Gennaro ML, North RJ (2003). Expression of Th1-mediated immunity in mouse lungs induces a Mycobacterium tuberculosis transcription pattern characteristic of nonreplicating persistence. PNAS 100, 241-246

Steel RGD, Torrie, JH (1980). Principles and procedures of statistics: a biometrical approach. 2nd ed. New York, McGraw-Hill

Todar K (2009). Mycobacterium tuberculosis and tuberculosis. In: Todar's Online Textbook of Bacteriology. Available from http://www.text bookofbacteriology.net/tuberculosis.html. Accessed May 15th, 2009

van Crevel R, Ottenhoff THM, van der Meer JWM (2002). Innate immunity to Mycobacterium tuberculosis. Clin Microbiol Rev 15, 294-309

Vesosky B, Flaherty DK, Joanne Turner J (2006). Th1 cytokines facilitate CD8-T-cell-mediated early resistance to infection with Mycobacterium tuberculosis in old mice. Infect Immun 74, 3314-3324

WHO (2012). Global tuberculosis report 2012. Available from http://www.who.int/tb/publications/ global_report/ en/. Accessed March 15th, 2013 